\title{
The status of rotigotine as a safe and effective alternative in the treatment of restless legs syndrome
}

This article was published in the following Dove Press journal:

Research and Reports in Transdermal Drug Delivery

5 April 2013

Number of times this article has been viewed

\author{
Pascale Bourgeois \\ Eric Frenette \\ CHUS a/s Service de Neurologie, \\ Sherbrooke, QC, Canada
}

Correspondence: Pascale Bourgeois CHUS a/s Service de Neurologie, 300 I I2e Avenue Nord, Sherbrooke, QC, JIH 5N4, Canada

Tel + I 8 I 9346 II I0 Ext I4589

Email pascale.bourgeois@usherbrooke.ca

Eric Frenette

CHUS a/s Service de Neurologie,

300 I 12e Avenue Nord, Sherbrooke,

QC, JIH 5N4, Canada

Tel +I 8 I 9346 III0 Ext I4589

Email eric.frenette@usherbrooke.ca

\begin{abstract}
Restless legs syndrome (RLS) is characterized by an urge to move the legs that occurs mainly with inactivity, and it is relieved by movement and is usually worse by the end of the day. It is highly prevalent, affecting $1.9 \%$ to $4.5 \%$ of the population, and although its etiology is uncertain, genetic factors seem to be involved. When symptoms are severe enough to warrant chronic therapy, dopamine receptor agonists are to be considered for initial treatment. Rotigotine, the most recently developed drug in this category, is the only one available for transdermal delivery in RLS. It was initially designed for the treatment of Parkinson's disease. The US Food and Drug Administration approved its use in cases of moderate to severe RLS in April 2012. Its efficacy has been well established in randomized placebo-controlled trials, as it appears to be especially useful in patients with daily symptoms. The most commonly reported side effect is local skin reaction. Complications such as augmentation, somnolence, or compulsive behavior may happen, although they seldom occur. The American Academy of Sleep Medicine clinical practice guideline recommends a "Guideline Level" for rotigotine, and European RLS guidelines provide a "level A" recommendation for short-term therapy; it also was the only dopaminergic agonist considered to be effective for the long-term management of RLS.
\end{abstract}

Keywords: restless legs syndrome, 2-rotigotine, dopamine receptor agonist

\section{Introduction}

Thomas de Quincey, a British writer of the 19th century, and author of "Confessions of an English-Opium eater", ${ }^{1}$ has described how his life had become miserable after suffering from insomnia. The symptoms he described were consistent with possible restless legs syndrome (RLS), and it was postulated that his opium addiction could have resulted from the need to treat himself. ${ }^{2}$

RLS was first described by Sir Thomas Willis in $1685,{ }^{2}$ but awareness of this disease was greatly enhanced following Ekbom's work ${ }^{3}$ beginning in the 1940s, to which we owe the appellation "restless legs syndrome." The term "Ekbom's disease" has also been used as a credit to his contribution.

RLS is a disorder frequently encountered in the general practitioner's office, but also in neurology, psychiatry, and sleep clinics. It may cause severe distress and has a negative impact on the quality of life of sufferers. Patients report an urge to move their legs, usually accompanied by an unpleasant sensation that is difficult to depict, which is temporarily relieved by movement. It usually emerges at the end of the day, and may compromise sleep.

Different pharmacological interventions have been used to treat this disorder, such as dopaminergic stimulation, or the usage of anticonvulsants or opioids, as De Quincey submit your manuscript | www.dovepress.com

Dovepress

http://dx.doi.org/10.2147/RRTD.S30575
Research and Reports in Transdermal Drug Delivery 2013:2 I-8

(C) 2013 Bourgeois and Frenette, publisher and licensee Dove Medical Press Ltd. This is an Open Access article which permits unrestricted noncommercial use, provided the original work is properly cited. 
discovered for himself. Rotigotine is the only transdermally delivered dopaminergic agonist available, enabling a continuous release of the drug through a 24-hour period. Here, we will first review RLS and the different components of this disorder, and then we shall ascertain the evidence supporting rotigotine as a potent agent in the treatment of this condition.

\section{Clinical features and diagnosis}

RLS is characterized by an urge to move the legs, usually accompanied by an uncomfortable sensation that is at least partially alleviated by movement. It occurs mainly with inactivity and particularly at the end of the day. This sensation is typically difficult to describe by patients, and may be reported as itching, burning, crawling, creeping, or stretching. It is a frequent condition, with as many as $1.9 \%$ to $4.5 \%$ of the population fulfilling the diagnostic criteria (Table 1). ${ }^{4,5}$ However, it remains an under-diagnosed entity, even when patients report their symptoms to their physician. ${ }^{6}$ In some cases, RLS may be caused by an underlying disease (iron deficiency anemia, end-stage chronic renal disease, peripheral neuropathy), but it is usually an idiopathic disorder for which the etiology is uncertain, although genetic factors are known to be involved..$^{7-16}$

Quality of life is greatly reduced by RLS, as much as in other chronic diseases like diabetes or depression. ${ }^{6,17,18}$ Prospective data have shown that women with RLS are at higher risk of developing clinical depression. ${ }^{19}$ Several cognitive functions might be affected by RLS, including verbal fluency and attention, ${ }^{20-22}$ mostly in patients with moderate to severe disease. RLS also causes a significant economic burden for patients and society alike, with a mean productivity loss estimated at 1 day per week in RLS sufferers. ${ }^{17}$ Many treatments are available, and here we will first review briefly some therapeutic options, and then we will examine the evidence supporting the use of rotigotine in RLS.

\section{Therapeutic options: dopaminergic stimulation}

The decision of whether or not to treat RLS is based on severity, frequency, and distress associated with the symptoms. Some individuals with mild, intermittent symptoms may not necessitate any treatment, or only on an occasional basis, while patients suffering from moderate to severe symptoms may require daily therapy. Many authors have provided reviews on the numerous treatment options, and two large consensuses have also provided specific guidelines for treating RLS. ${ }^{23-29}$

Dopaminergic receptor-stimulating drugs represent the most effective and the most widely prescribed drugs in RLS. These include levodopa and all the dopamine receptor agonists (Table 2). These medications are associated with well-known side effects such as nausea, drowsiness, and dizziness. More bothersome complications include sleep attacks, compulsive behavior, and augmentation, which have been recognized as complications related to dopaminergic therapy for RLS since their first description in 1996 following levodopa-carbidopa usage. ${ }^{30}$ Augmentation is characterized by a worsening of symptoms after an initial positive response to RLS treatment. It may cause earlier occurrence, with increasing intensity or extension to other body parts. Increasing the doses of the dopaminergic agent

Table I Diagnostic criteria of RLS

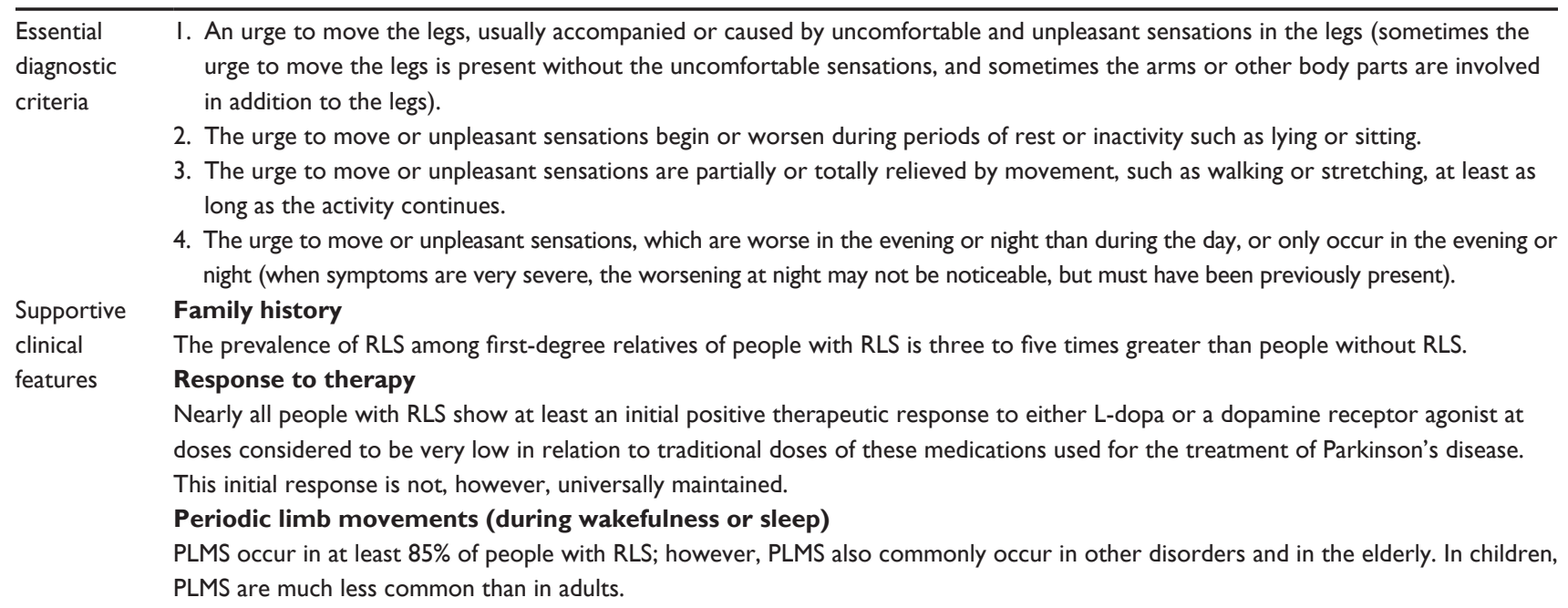

Abbreviations: RLS, restless legs syndrome; PLMS, periodic limb movements in sleep. 
Table 2 Dopaminergic stimulation

\begin{tabular}{|c|c|c|c|c|c|}
\hline Class & Medication & Mechanism & $\begin{array}{l}T_{\max } \\
\text { (hours) }\end{array}$ & $\begin{array}{l}\text { Half-life } \\
\text { (hours) }\end{array}$ & Comments \\
\hline Dopamine therapy & $\begin{array}{l}\text { Levodopa-carbidopa/ } \\
\text { benserazide }\end{array}$ & Precursor of dopamine & $0.5-2$ & $\mathrm{I}-3$ & $\begin{array}{l}\text { Absorption decreases } \\
\text { when taken with meals }\end{array}$ \\
\hline Ergot-derived & Bromocriptine & $\mathrm{D}_{2}$ agonist, partial $\mathrm{D}_{1}$ agonist & $\mathrm{I}-\mathrm{I} .5$ & $6-8$ & Liver metabolism \\
\hline $\begin{array}{l}\text { dopamine receptor } \\
\text { agonists }\end{array}$ & Cabergoline & $\begin{array}{l}\mathrm{D}_{2} \text { selective agonist } \\
5-\mathrm{HT}_{2 \mathrm{~b}} \text { agonist }\end{array}$ & 2.5 & 65 & $\begin{array}{l}\text { Causes cardiac valvular } \\
\text { fibrosis }\end{array}$ \\
\hline Nonergot-derived & Ropinirole & $\mathrm{D}_{2} / \mathrm{D}_{3}$ agonist & 1.5 & 6 & Liver metabolism \\
\hline \multirow[t]{2}{*}{$\begin{array}{l}\text { dopamine receptor } \\
\text { agonists }\end{array}$} & Pramipexole & $\mathrm{D}_{2} / \mathrm{D}_{3}$ agonist & $\mathrm{I}-3$ & 10 & $\begin{array}{l}\text { Largely excreted } \\
\text { unchanged in urine }\end{array}$ \\
\hline & Rotigotine & $D_{3} / D_{2} / D_{1}$ agonist & 14 & $5-7$ & $\begin{array}{l}\text { Liver metabolism } \\
65 \%-70 \% \text { excreted by } \\
\text { the kidneys }\end{array}$ \\
\hline
\end{tabular}

Abbreviation: $\mathrm{T}_{\max }$, time to peak concentration.

should transiently relieve the symptoms, but will eventually lead to further deterioration. ${ }^{31}$

\section{Levodopa}

Multiple small clinical trials support the efficacy of levodopa in RLS. ${ }^{24}$ Its short time to peak concentration makes it suitable for intermittent as-needed treatment. However, a high rate of augmentation (up to $80 \%$ ), which may be severe (leading to discontinuation in $50 \%$ of patients), has been reported with chronic therapy. ${ }^{23,30}$ Because of its short half-life, levodopa may also be associated with a rebound phenomenon, leading to late-night or morning recurrence of symptoms ${ }^{24}$ Considering these complications, when daily therapy is needed, other alternatives should be considered.

\section{Ergolic dopamine receptor agonist}

Ergot-derived dopamine receptor agonists include bromocriptine and cabergoline. Evidence of the efficacy of bromocriptine is weaker than that of cabergoline. According to a recent meta-analysis, ${ }^{25}$ the latter medication, presumably because of its longer half-life, yielded superior therapeutic efficacy and offered better daytime relief of symptoms compared to the relatively short-acting non-ergolic oral dopamine agonists. This was associated with a positive impact on quality of life. However, since it has a recognized risk of cardiac valvular fibrosis, it can no longer be advocated for the treatment of RLS.

\section{Nonergolic dopamine receptor agonist}

Nonergot-derived dopamine receptor agonists include rotigotine, ropinirole, and pramipexole. They are frequently used as first-line therapy in clinical practice and are potent drugs for alleviating the symptoms of RLS. A recent meta-analysis con- cluded that the clinical benefit is similar between ropinirole and pramipexole, although no study has compared these drugs in a head-to-head trial. As a newer agent, rotigotine has not been compared to the two latter dopamine receptor agonists. Compared to placebo, transdermal delivery was shown to be associated with better daytime control of symptoms and improved quality of life. ${ }^{26}$

\section{Therapeutic options: rotigotine}

Rotigotine was first approved for use in early-stage Parkinson's disease by the Food and Drug Administration (FDA) in 2007, but was withdrawn from the market in 2008 because of concerns about inconsistent absorption due to drug crystallization. Since then, a rotigotine patch $\left(\right.$ Neupro $^{\circledR}$, UCB SA, Brussels, Belgium) was reformulated to prevent crystallization. It was approved again in April 2012 for the treatment of moderate to severe RLS. It was expected that the 24-hour delivery system would have some benefit over the other drugs for relieving diurnal symptoms.

\section{Structure, mode of action, and pharmacokinetics}

Rotigotine, or S-(-)-2-(N-propyl-N-2-thienylethylamino)5 -hydroxytetralin hydrochloride, is a nonergolic dopamine $\mathrm{D}_{3} / \mathrm{D}_{2} / \mathrm{D}_{1}$ agonist that also has activity on alpha ${ }_{2}$-adrenergic, 5-HT ${ }_{1 \mathrm{~A}}$, and 5-HT receptors. $^{32}$ It is a silicone-based transdermal system that releases the drug in a continuous manner over 24 hours. ${ }^{33}$ Between $31 \%$ and $62 \%$ of the total drug content is delivered to the skin, with a high interindividual variability of $54 \%$, but with low variability within individuals (15\%). ${ }^{34}$ The drug is mostly eliminated by renal excretion $(65 \%-70 \%)$, with a half-life of 5 to 7 hours, and it is barely detectable 96 hours after removal of the patch..$^{35,36}$ 


\section{Clinical studies of rotigotine in RLS}

Rotigotine was first assessed in the treatment of Parkinson's disease. ${ }^{33,37}$ Five randomized, placebo-controlled clinical trials evaluated rotigotine in the treatment of RLS (Table 3).

Two small trials have provided significant data concerning clinical efficacy and objective sleep. A 1-week pilot trial published in 2004 showed a positive dose-response, but only the $4.5 \mathrm{mg}$ dose reached superiority against placebo. ${ }^{38}$

A 2010 4-week polysomnographic study compiled data supporting a significant reduction in periodic limb movement in sleep, a frequently comorbid condition in RLS, altogether with a reduction in RLS motor symptoms. ${ }^{39}$

Larger clinical trials have led to the approval of rotigotine by the FDA. The first one, published in 2008, consisted of a 6-month randomized, placebo-controlled trial of 458 patients comparing doses ranging from $1 \mathrm{mg} / 24$ hours to $3 \mathrm{mg} / 24$ hours. ${ }^{40}$ It confirmed efficacy both on the International Restless Legs Severity scale (IRLS) and the Clinical
Global Impression scale for all three doses against placebo. Skin reactions were frequent (43\%), but severe reactions were seldom seen $(1.8 \%)$.

Hening et $\mathrm{a}^{41}$ have published a similar trial in 2010 involving 505 patients randomized either to placebo or to one of four different doses ( $0.5 \mathrm{mg} /$ day, $1 \mathrm{mg} /$ day, $2 \mathrm{mg} /$ day, or $3 \mathrm{mg} /$ day) with 6 months of follow-up. Efficacy measures with the IRLS score were superior to placebo with the $2 \mathrm{mg}$ /day and $3 \mathrm{mg} /$ day doses. The retention rate over 6 months was $63 \%$, with adverse events being the most common cause of discontinuation $(20 \%)$.

Efficacy and safety were evaluated in a 6-week, randomized, placebo-controlled, dose-finding trial comparing five different doses $(0.5 \mathrm{mg} / 24$ hours, $1 \mathrm{mg} / 24$ hours, $2 \mathrm{mg} / 24$ hours, $3 \mathrm{mg} / 24$ hours, $4 \mathrm{mg} / 24$ hours) in 341 patients. ${ }^{42}$ The lowest dose was ineffective, but all others proved to be superior to placebo, with a dose-dependent response observed except for the $4 \mathrm{mg} / 24$ hour dose, in which no additional benefit was detected compared to the $3 \mathrm{mg} / 24$ hour dose.

Table 3 Randomized controlled trials of rotigotine in RLS

\begin{tabular}{|c|c|c|c|}
\hline Clinical trial & Methodology & $\begin{array}{l}\text { Results of efficacy } \\
\text { (IRLS sum score versus baseline) }\end{array}$ & $\begin{array}{l}\text { Side effects reported in } \\
>5 \% \text { patients }\end{array}$ \\
\hline Stiasny-Kolster et $\mathrm{al}^{38}$ & $\begin{array}{l}\text { I-week pilot trial } \\
63 \text { patients randomized to placebo or } \\
\text { rotigotine, I.I } 25 \mathrm{mg}, 2.5 \mathrm{mg} \text {, or } \\
4.5 \mathrm{mg}\end{array}$ & $\begin{array}{l}\text { Placebo: }-7.7 \\
\text { I. } 125 \mathrm{mg}:-10.5 \\
2.5 \mathrm{mg}:-12.3 \\
4.5 \mathrm{mg}:-15.7^{*}\end{array}$ & $\begin{array}{l}\text { Application site reaction, } 26.5 \% \\
\text { Headache, } 22.4 \%\end{array}$ \\
\hline Oertel et $\mathrm{al}^{42}$ & $\begin{array}{l}6 \text { weeks } \\
34 \text { I patients randomized to placebo or } \\
\text { rotigotine, } 0.5 \mathrm{mg} / 24 \text { hours, } \\
\text { I mg/24 hours, } 2 \mathrm{mg} / 24 \text { hours, } \\
3 \mathrm{mg} / 24 \text { hours, or } 4 \mathrm{mg} / 24 \text { hours }\end{array}$ & $\begin{array}{l}\text { Placebo: }-9.3 \\
0.5 \mathrm{mg} / 24 \text { hours: }-10.5 \\
\text { I mg/24 hours: }-15.1^{*} \\
2 \mathrm{mg} / 24 \text { hours: }-15.7^{*} \\
3 \mathrm{mg} / 24 \text { hours: }-17.5^{*} \\
4 \mathrm{mg} / 24 \text { hours: }-14.8^{*}\end{array}$ & $\begin{array}{l}\text { Application site reaction, } 17.5 \% \\
\text { Nausea, } 14.4 \% \\
\text { Headache, } 7.7 \% \\
\text { Fatigue, } 6.7 \%\end{array}$ \\
\hline Trendwalker et $\mathrm{al}^{40}$ & $\begin{array}{l}6 \text { months } \\
458 \text { patients randomized to placebo or } \\
\text { rotigotine I mg/ } 24 \text { hours, } \\
2 \mathrm{mg} / 24 \text { hours, or } 3 \mathrm{mg} / 24 \text { hours }\end{array}$ & $\begin{array}{l}\text { Placebo: }-8.6 \\
\text { I mg/24 hours: }-13.7 * \\
2 \text { mg/24 hours: }-16.2 * \\
3 \text { mg/24 hours: }-16.8 *\end{array}$ & $\begin{array}{l}\text { Application site reaction, } 43 \% \\
\text { Nausea, } 16 \% \\
\text { Headache, } 13 \% \\
\text { Fatigue, } 13 \%\end{array}$ \\
\hline Oertel et $\mathrm{al}^{39}$ & $\begin{array}{l}4 \text { weeks } \\
67 \text { patients randomized to placebo or } \\
\text { rotigotine ( } 1: 2) \text { with titration up } \\
\text { to optimal dose (I mg/ } 24 \text { hours } \\
\text { to } 3 \mathrm{mg} / 24 \text { hours) } \\
\text { Polysomnographic assessment } \\
\text { of periodic limb movement }\end{array}$ & $\begin{array}{l}\text { Placebo: }-9.9 \\
\text { Rotigotine: }-16.9 *\end{array}$ & $\begin{array}{l}\text { Application site reaction, } 17.4 \% \\
\text { Nausea, } 21.7 \% \\
\text { Headache, } 17.4 \% \\
\text { Fatigue, } 8.7 \% \\
\text { Somnolence, } 10.9 \% \\
\text { Constipation, } 6.5 \% \\
\text { Insomnia, } 6.5 \% \\
\text { Dizziness, } 6.5 \%\end{array}$ \\
\hline Hening et $\mathrm{al}^{41}$ & $\begin{array}{l}6 \text { months } \\
505 \text { patients randomized to placebo or } \\
\text { rotigotine } 0.5 \mathrm{mg} / 24 \text { hours, } \\
\mathrm{I} \mathrm{mg/24} \mathrm{hours,} 2 \mathrm{mg} / 24 \text { hours, } \\
3 \mathrm{mg} / 24 \text { hours }\end{array}$ & $\begin{array}{l}\text { Placebo: }-9.0 \\
0.5 \mathrm{mg} / 24 \text { hours: }-10.9 \\
\text { I mg/24 hours : }-11.1 \\
2 \mathrm{mg} / 24 \text { hours : }-13.4^{*} \\
3 \mathrm{mg} / 24 \text { hours: }-14.3^{*}\end{array}$ & $\begin{array}{l}\text { Application site reaction, } 27 \% \\
\text { Nausea, } 18.1 \% \\
\text { Headache, } 11.6 \% \\
\text { Fatigue, } 7 \% \\
\text { Somnolence, } 11 \% \\
\text { Pruritus, } 5 \% \\
\text { Dizziness, } 5 \%\end{array}$ \\
\hline
\end{tabular}

Note: *Indicates statistical significance compared to placebo $(P<0.05)$.

Abbreviations: RLS, restless legs syndrome; IRLS, International Restless Legs Severity scale. 
Over the 1-year open extension of this study, ${ }^{43}$ the retention rate was $74.6 \%$. Discontinuation was most commonly explained by adverse events (17\%), most of which were application site reactions. Efficacy was maintained with a 17.4 decrease in the IRLS score. Tolerability was considered to be "good" or "very good" in a large proportion of the remaining patients $(80.3 \%)$. The most common adverse event was local skin reaction, which led to discontinuation of the drug in $13.2 \%$ of patients. Nausea and fatigue were the two other side effects most frequently reported. Augmentation was not evaluated in a standardized way, and no patients reported occurrence of these symptoms. A 5-year open extension study of the same cohort revealed that efficacy remained substantial over the years. ${ }^{44}$ However, the retention rate was somewhat low $(43 \%$ of patients entering the open label extension phase). Adverse events were the most common reason for discontinuation (30\% of the cohort). Application site reaction was frequent (58\%), and led to discontinuation in 19\% of patients. Lack of efficacy led to treatment interruption in $11 \%$ of patients. Clinically significant augmentation was retrospectively assessed, and was reported in $13 \%$ of patients. In the patients who completed the study, 39\% were free of RLS symptoms, and the mean IRLS score had declined from 27.9 to 9.0 (maximal score of 40). This trial suggested that rotigotine was suitable for long-term treatment in patients with moderate to severe RLS. A post hoc analysis including patients taking approved dosages ( $1 \mathrm{mg} /$ day, $2 \mathrm{mg} /$ day, or $3 \mathrm{mg} /$ day) indicated that only $23 \%$ of them completed the 5 years of follow-up. ${ }^{45}$ Forty percent were excluded because of adjustment of medication outside of this range, and $37 \%$ stopped while taking appropriate dosage, mostly because of adverse events (25\%) or less frequently because of lack of efficacy (6\%). Efficacy outcomes were maintained through the 5 years of follow-up in the remaining patients.

Altogether, these studies provided strong data supporting the efficacy of rotigotine over placebo, both in the short- and long-term treatment of RLS. Regarding the high drop-out rate in the open-label phase extension studies, tolerability seems to remain a significant limiting factor, and will be further discussed here.

\section{Adverse and side effect profile of rotigotine}

Dopaminergic receptor stimulation is accompanied by side effects that are common to all drug formulations, including nausea, drowsiness, sleep attacks, and compulsive behavior, all of which need to be closely monitored. Rotigotine is also specifically associated with local skin reactions arising in approximately half of patients, and they are mostly mild in intensity, but they are still a frequent cause of discontinuation in clinical trials.

Impulsive behavior caused by dopaminergic therapy is a serious complication that can have disastrous consequences for patients. Hypersexuality, compulsive overeating, pathological gambling, and punding have been reported in some patients treated with rotigotine for Parkinson's disease. ${ }^{46,47}$ In these case reports, patients received between $6 \mathrm{mg}$ and $22.5 \mathrm{mg}$ per day of rotigotine, and all of the patients were also taking levodopa. None of the placebo-controlled trials that led to the approval of rotigotine in the treatment of RLS reported significant increases in this complication. However, a recent retrospective study of a small cohort of 28 patients reported rates of impulsive behavior as high as $21 \% .{ }^{48}$ These patients had no prior history of such behavior, and this complication occurred even in individuals taking low doses of rotigotine (mean $3.8 \mathrm{mg} /$ day). This data is useful in reminding clinicians to be aware of this problem, even with low doses of dopaminergic agonists, in order to detect it.

Sleep attacks while driving were not reported in clinical trials assessing rotigotine in RLS; however, they occurred in one patient taking the $13.5 \mathrm{mg}$ dose in the treatment group of a trial for Parkinson's disease. ${ }^{33}$ One patient also lost consciousness while driving in this trial; he was receiving a dose of $18 \mathrm{mg}$. A case report also described sleep attacks in a patient with Parkinson's disease on $8 \mathrm{mg} / 24$ hours of rotigotine. ${ }^{49}$ To our knowledge, these effects have not yet been described in RLS, and this may be attributable to the lower dosage used for this disorder.

It was expected that the continuous delivery system of the transdermal therapy could lower or even abolish augmentation rates, based on the hypothesis that development of augmentation is related to the pulsatile stimulation of dopaminergic receptors. However, augmentation was reported in a significant proportion of patients (18\% to $43 \%)$ during clinical trials, although it was rarely severe enough to lead to discontinuation of therapy. ${ }^{39-42}$ As mentioned earlier, long-term treatment was well tolerated, with only $13 \%$ of patients developing augmentation over 5 years of therapy. ${ }^{44}$ It should be reminded, however, that patients with significant side effects, including augmentation, were not included in the extension phase study, which may explain the lower risk observed compared to the placebo-controlled trial. A recent retrospective study showed that none of the 748 patients treated for 18 months with rotigotine discontinued the treatment because of augmentation. The authors concluded that clinically relevant augmentation was rare with rotigotine, and 
was probably lower compared to other dopamine receptor agonists. ${ }^{50}$ The study with Japanese subjects reported a similar, very low risk of augmentation $(2.7 \%)$ in the extension phase study. ${ }^{51}$ The retrospective nature of these studies and the lack of control medication in the extension phase may effectively introduce bias in the final interpretation of the harvested data. However, the relative absence of augmentation in these patients is encouraging and implies that continuous delivery of the drug helps to prevent this complication more effectively than with the pulsatile dopaminergic stimulation seen with orally taken agents. Head-to-head comparisons of rotigotine with other dopamine receptor agonists in a prospective fashion would be the best way to put this issue to rest.

Nausea with rotigotine has been consistently reported in trials, affecting $16 \%$ to $22 \%$ of patients receiving the drug. ${ }^{39-42}$ Dizziness and somnolence were also reported, ${ }^{26,39,41}$ with somnolence being dose-dependent in one study. ${ }^{41}$ In the aforementioned placebo-controlled trials, nondopaminergicrelated adverse events with a $\geq 5 \%$ incidence included headache and augmentation. ${ }^{39-42}$ Cardiac safety was evaluated with supratherapeutic doses of rotigotine ( $24 \mathrm{mg} / 24$ hours) in patients with advanced Parkinson's disease, with no significant consequence on QT/QTc intervals. ${ }^{52}$ In RLS trials, prolongment of the QT interval has been reported in one patient receiving $4 \mathrm{mg} /$ day. ${ }^{43}$

\section{Therapeutic options: alternatives}

Avoiding exacerbating factors should always be considered part of the treatment plan. Dopamine receptor antagonists like antinausea drugs, neuroleptics, or some antidepressants may cause or worsen symptoms of RLS. Iron therapy is controversial, but considering its safety profile, it seems acceptable to treat patients with a low ferritin level. ${ }^{53}$ Some anticonvulsant drugs may be used to treat RLS. Gabapentin, and its prodrug, gabapentin enacarbil (FDA approved in 2011), are effective and well tolerated. ${ }^{54}$ Some data also support the use of pregabalin. Evidence for efficacy with other anticonvulsants, including carbamazepine, is weaker. ${ }^{23,26}$ Opioids should not be considered as first-line agents, but they represent an excellent option for patients not getting sufficient relief from other drug categories. With careful monitoring of doses, tolerance and dependence can be avoided. Sufficient data supports the usage of oxycodone, while the use of methadone and tramadol are considered investigational. ${ }^{26}$

\section{Guidelines for RLS therapy}

The American Academy of Sleep Medicine has recently published a clinical practice guideline on the treatment of RLS. ${ }^{29}$
The levels of recommendation were graded as "standard," "guideline," or "option," based on the level of evidence and on the benefit-to-harm ratio. Therapies with a "standard" level of recommendation included pramipexole and ropinirole. A "guideline" level of recommendation was given to levodopa with dopa decarboxylase inhibitor, opioids, gabapentin enacarbil, and cabergoline. Therapies with an "option" level of recommendation include carbamazepine, gabapentin, pregabalin, clonidine, and iron supplementation in patients with low ferritin levels. Pergolide received a "standard against" level of recommendation because of the risks of heart valve damage with this medication. No recommendations were made initially on rotigotine despite high levels of evidence for its efficacy. Following its approval by the FDA in April 2012, an update of these guidelines was published, and rotigotine has received a "guideline" level of recommendation, on par with the other dopaminergic therapies. ${ }^{55}$

European guidelines provided level A recommendations for the short-term control of symptoms with rotigotine, pramipexole, ropinirole, gabapentin, gabapentin enacarbil, and pregabalin. ${ }^{28}$ For the purpose of long-term therapy, rotigotine was considered effective, gabapentin enacarbil was probably effective, and ropinirole, pramipexole and gabapentin were considered possibly effective.

\section{Conclusion}

In conclusion, RLS is a frequent, although under-diagnosed condition that may cause significant morbidity in some individuals. Etiology is unknown, although robust evidence suggests that genetic factors play an important role in its genesis. Many treatment options are available. Dopamine receptor agonists are considered the first-line therapy when daily treatment is needed. Rotigotine is the only FDAapproved transdermal drug for this disorder. This continuous delivery system may help control daily RLS symptoms, and has been shown to be superior to placebo in multiple trials. Long-term usage has been shown to provide sustained efficacy for at least 5 years. Adverse effects related to dopaminergic stimulation, like nausea, impulsive behavior, and augmentation, may occur and call for physician awareness and regular follow-up appointments to detect their occurrence and to determine an appropriate intervention plan.

\section{Acknowledgments}

Dr Bourgeois is a Senior Resident in the Neurology program at the University of Sherbrooke Hospital Center (CHUS). Dr Frenette is an Assistant Professor of Neurology at the University of Sherbrooke. 


\section{Disclosure}

The authors report no conflicts of interest in this work.

\section{References}

1. De Quincey T. Confessions of an English Opium-Eater and Suspira de Profundis. Boston : Ticknor, Reed, and Fields' 1953.

2. Miranda M, Williams AM, Garcia-Borreguero D. Thomas de Quincey and his restless legs symptoms as depicted in "Confessions of an English Opium-Eater”. Mov Disord. 2010;25(13):2006-2009.

3. Teive HA, Munhoz RP, Barbosa ER. Professor karl-axel ekbom and restless legs syndrome. Parkinsonism Relat Disord. 2009;15(4): 254-257.

4. Ohayon MM, O'Hara R, Vitiello MV. Epidemiology of restless legs syndrome: a synthesis of the literature. Sleep Med Rev. 2012;16(4): 283-295.

5. Allen RP, Picchietti D, Hening WA, Trenkwalder C, Walters AS, Montplaisi J; for Restless Legs Syndrome Diagnosis and Epidemiology workshop at the National Institutes of Health, International Restless Legs Syndrome Study Group. Restless legs syndrome: diagnostic criteria, special considerations, and epidemiology. A report from the restless legs syndrome diagnosis and epidemiology workshop at the National Institutes of Health. Sleep Med. 2003;4(2):101-119.

6. Allen RP, Walters AS, Montplaisir J, et al. Restless legs syndrome prevalence and impact: REST general population study. Arch Intern Med. 2005;165(11):1286-1292.

7. Balaban H, Bayrakli F, Kartal U, Pinarbasi E, Topaktas S, Kars HZ. A novel locus for restless legs syndrome on chromosome 13q. Eur Neurol. 2012;68(2):111-116.

8. Kemlink D, Plazzi G, Vetrugno R, et al. Suggestive evidence for linkage for restless legs syndrome on chromosome 19p13. Neurogenetics. 2008;9(2):75-82.

9. Levchenko A, Provost S, Montplaisir JY, et al. A novel autosomal dominant restless legs syndrome locus maps to chromosome 20p13. Neurology. 2006;67(5):900-901.

10. Pichler I, Marroni F, Volpato CB, et al. Linkage analysis identifies a novel locus for restless legs syndrome on chromosome $2 \mathrm{q}$ in a South Tyrolean population isolate. Am J Hum Genet. 2006;79(4): 716-723.

11. Sas AM, Di Fonzo A, Bakker SL, et al. Autosomal dominant restless legs syndrome maps to chromosome 20p13 (RLS-5) in a Dutch kindred. Mov Disord. 2010;25(11):1715-1722.

12. Skehan EB, Abdulrahim MM, Parfrey NA, Hand CK. A novel locus for restless legs syndrome maps to chromosome 19p in an Irish pedigree. Neurogenetics. 2012;13(2):125-132.

13. Winkelmann J, Muller-Myhsok B, Wittchen HU, et al. Complex segregation analysis of restless legs syndrome provides evidence for an autosomal dominant mode of inheritance in early age at onset families. Ann Neurol. 2002;52(3):297-302.

14. Winkelmann J, Czamara D, Schormair B, et al. Genome-wide association study identifies novel restless legs syndrome susceptibility loci on 2p14 and 16q12.1. PLoS Genet. 2011;7(7):e1002171.

15. Xiong L, Jang K, Montplaisir J, et al. Canadian restless legs syndrome twin study. Neurology. 2007;68(19):1631-1633.

16. Xiong L, Montplaisir J, Desautels A, et al. Family study of restless legs syndrome in Quebec, Canada: clinical characterization of 671 familial cases. Arch Neurol. 2010;67(5):617-622.

17. Allen RP, Bharmal M, Calloway M. Prevalence and disease burden of primary restless legs syndrome: results of a general population survey in the United States. Mov Disord. 2011;26(1):114-120.

18. Kushida C, Martin M, Nikam P, et al. Burden of restless legs syndrome on health-related quality of life. Qual Life Res. 2007;16(4): 617-624.

19. LiY, Mirzaei F, O'Reilly EJ, et al. Prospective study of restless legs syndrome and risk of depression in women. Am J Epidemiol. 2012;176(4): 279-288.
20. Fulda S, Beitinger ME, Reppermund S, Winkelmann J, Wetter TC. Short-term attention and verbal fluency is decreased in restless legs syndrome patients. Mov Disord. 2010;25(15):2641-2648.

21. Gamaldo CE, Benbrook AR, Allen RP, Oguntimein O, Earley CJ. A further evaluation of the cognitive deficits associated with restless legs syndrome (RLS). Sleep Med. 2008;9(5):500-505.

22. Pearson VE, Allen RP, Dean T, Gamaldo CE, Lesage SR, Earley CJ. Cognitive deficits associated with restless legs syndrome (RLS). Sleep Med. 2006;7(1):25-30.

23. Buchfuhrer MJ. Strategies for the treatment of restless legs syndrome. Neurotherapeutics. 2012;9(4):776-790.

24. de Biase S, Merlino G, Lorenzut S, Valente M, Gigli GL. ADMET considerations for restless leg syndrome drug treatments. Expert Opin Drug Metab Toxicol. 2012;8(10):1247-1261.

25. Hornyak M, Trenkwalder C, Kohnen R, Scholz H. Efficacy and safety of dopamine agonists in restless legs syndrome. Sleep Med. 2012;13(3): $228-236$.

26. Trenkwalder C, Hening WA, Montagna P, et al. Treatment of restless legs syndrome: an evidence-based review and implications for clinical practice. Mov Disord. 2008;23(16):2267-2302.

27. Zintzaras E, Kitsios GD, Papathanasiou AA, et al. Randomized trials of dopamine agonists in restless legs syndrome: a systematic review, quality assessment, and meta-analysis. Clin Ther. 2010;32(2): 221-237.

28. Garcia-Borreguero D, Ferini-Strambi L, Kohnen R, et al. European guidelines on management of restless legs syndrome: report of a joint task force by the European Federation of Neurological Societies, the European Neurological Society and the European Sleep Research Society. Eur J Neurol. 2012;19(11):1385-1396.

29. Aurora RN, Kristo DA, Bista SR, et al. The treatment of restless legs syndrome and periodic limb movement disorder in adults-an update for 2012: practice parameters with an evidence-based systematic review and meta-analyses: an American Academy of Sleep Medicine Clinical Practice Guideline. Sleep. 2012;35(8):1039-1062.

30. Allen RP, Earley CJ. Augmentation of the restless legs syndrome with carbidopa/levodopa. Sleep. 1996;19(3):205-213.

31. García-Borreguero D, Allen RP, Kohnen R, et al; for International Restless Legs Syndrome Study Group. Diagnostic standards for dopaminergic augmentation of restless legs syndrome: report from a World Association of Sleep Medicine-International Restless Legs Syndrome Study Group consensus conference at the Max Planck Institute. Sleep Med. 2007;8(5):520-530.

32. Reynolds NA, Wellington K, Easthope SE. Rotigotine: in Parkinson's disease. CNS Drugs. 2005;19(11):973-981.

33. Parkinson Study Group. A controlled trial of rotigotine monotherapy in early Parkinson's disease. Arch Neurol. 2003;60(12): 1721-1728.

34. Elshoff JP, Braun M, Andreas JO, Middle M, Cawello W. Steady-state plasma concentration profile of transdermal rotigotine: an integrated analysis of three, open-label, randomized, phase I multiple dose studies. Clin Ther. 2012;34(4):966-978.

35. Cawello W, Wolff HM, Meuling WJ, Horstmann R, Braun M. Transdermal administration of radiolabelled [14C]rotigotine by a patch formulation: a mass balance trial. Clin Pharmacokinet. 2007;46(10): $851-857$.

36. Cawello W, Braun M, Boekens H. Absorption, disposition, metabolic fate, and elimination of the dopamine agonist rotigotine in man: administration by intravenous infusion or transdermal delivery. Drug Metab Dispos. 2009;37(10):2055-2060.

37. Watts RL, Jankovic J, Waters C, Rajput A, Boroojerdi B, Rao J. Randomized, blind, controlled trial of transdermal rotigotine in early Parkinson disease. Neurology. 2007;68(4):272-276.

38. Stiasny-Kolster K, Kohnen R, Schollmayer E, Möller JC, Oertel WH; for Rotigotine Sp 666 Study Group. Patch application of the dopamine agonist rotigotine to patients with moderate to advanced stages of restless legs syndrome: a double-blind, placebo-controlled pilot study. Mov Disord. 2004;19(12):1432-1438. 
39. Oertel WH, Benes H, Garcia-Borreguero D, et al. Rotigotine transdermal patch in moderate to severe idiopathic restless legs syndrome: a randomized, placebo-controlled polysomnographic study. Sleep Med. 2010;11(9):848-856.

40. Trenkwalder C, Benes H, Poewe W, et al; for SP790 Study Group. Efficacy of rotigotine for treatment of moderate-to-severe restless legs syndrome: a randomised, double-blind, placebo-controlled trial. Lancet Neurol. 2008;7(7):595-604.

41. Hening WA, Allen RP, Ondo WG, et al; for SP792 Study Group. Rotigotine improves restless legs syndrome: a 6-month randomized, double-blind, placebo-controlled trial in the United States. Mov Disord. 2010;25(11):1675-1683.

42. Oertel WH, Benes H, Garcia-Borreguero D, et al; for Rotigontine SP 709 Study Group. Efficacy of rotigotine transdermal system in severe restless legs syndrome: a randomized, double-blind, placebocontrolled, six-week dose-finding trial in Europe. Sleep Med. 2008; 9(3):228-239.

43. Oertel WH, Benes H, Garcia-Borreguero D, et al; for Rotigotine SP710 Study Group. One year open-label safety and efficacy trial with rotigotine transdermal patch in moderate to severe idiopathic restless legs syndrome. Sleep Med. 2008;9(8):865-873.

44. Oertel W, Trenkwalder C, Beneš H, et al; for SP710 Study Group. Long-term safety and efficacy of rotigotine transdermal patch for moderate-to-severe idiopathic restless legs syndrome: a 5-year open-label extension study. Lancet Neurol. 2011;10(8):710-720.

45. Dohin E, Högl B, Ferini-Strambi L, et al. Safety and efficacy of rotigotine transdermal patch in patients with restless legs syndrome: a post-hoc analysis of patients taking 1-3 mg/24 h for up to 5 years. Expert Opin Pharmacother. 2013;14(1):15-25.

46. Hinnell C, Hulse N, Martin A, Samuel M. Hypersexuality and compulsive over-eating associated with transdermal dopamine agonist therapy. Parkinsonism Relat Disord. 2011;17(4):295-296.
47. Wingo TS, Evatt M, Scott B, Freeman A, Stacy M. Impulse control disorders arising in 3 patients treated with rotigotine. Clin Neuropharmacol. 2009;32(2):59-62.

48. Schreglmann SR, Gantenbein AR, Eisele G, Baumann CR. Transdermal rotigotine causes impulse control disorders in patients with restless legs syndrome. Parkinsonism Relat Disord. 2012;18(2):207-209.

49. Garcia Ruiz PJ. Sleep attack associated to rotigotine. Clin Neuropharmacol. 2009;32(6):365.

50. Benes H, García-Borreguero D, Ferini-Strambi L, Schollmayer E, Fichtner A, Kohnen R. Augmentation in the treatment of restless legs syndrome with transdermal rotigotine. Sleep Med. 2012;13(6):589-597.

51. Inoue Y, Hirata K, Hayashida K, Hattori N, TomidaT, Garcia-Borreguero D; for Rotigotine Study Group. Efficacy, safety and risk of augmentation of rotigotine for treating restless legs syndrome. Prog Neuropsychopharmacol Biol Psychiatry. 2013;40:326-333.

52. Malik M, Andreas JO, Hnatkova K, et al. Thorough QT/QTe study in patients with advanced Parkinson's disease: cardiac safety of rotigotine. Clin Pharmacol Ther. 2008;84(5):595-603.

53. Trotti LM, Bhadriraju S, Becker LA. Iron for restless legs syndrome. Cochrane Database Syst Rev. 2012;5:CD007834.

54. Lee DO, Ziman RB, Perkins AT, Poceta JS, Walters AS, Barrett RW; for XP053 Study Group. A randomized, double-blind, placebo-controlled study to assess the efficacy and tolerability of gabapentin enacarbil in subjects with restless legs syndrome. J Clin Sleep Med. 2011;7(3): 282-292.

55. Aurora RN, Kristo DA, Bista SR, et al. Update to the AASM Clinical Practice Guideline: "The treatment of restless legs syndrome and periodic limb movement disorder in adults-an update for 2012: practice parameters with an evidence-based systematic review and meta-analyses". Sleep. 2012;35(8):1037.
Research and Reports in Transdermal Drug Delivery

\section{Publish your work in this journal}

Research and Reports in Transdermal Drug Delivery is an international, peer-reviewed, open access online journal publishing original research, study protocols, reviews, editorials and commentaries on all aspects of transdermal drug delivery. Specific topics in the journal include: Laboratory and clinical development of drug delivery systems including preclinical, clinical studies and protocols; Rationale and basic science; Drug

\section{Dovepress}

delivery via gels, creams or patches; Use of chemical drug penetration enhancers Patient acceptability studies; and pharmacoeconomic and clinical outcome studies. The manuscript management system is completely online and includes a very quick and fair peer-review system, which is all easy to use. Visit http://www.dovepress.com/ testimonials.php to read real quotes from published authors. 